\title{
Existence of Local Newspapers in Rivers and Bayelsa States (1996-2016)
}

\author{
Otikor Njanubok Samuel S. C. J. Mbazie \\ Department of Linguistics and Communication Studies, University of Port Harcourt \\ P.M.B. 5323, Choba, Rivers State, Nigeria
}

\begin{abstract}
Considering the need to historically document local newspapers, this study examined the existence and lifespan of local newspapers in Rivers and Bayelsa States between 1996 and 2016. The circulation spiral theory provided the theoretical framework for the study. Three research questions were formulated to guide the study. The population of the study was drawn from 214 production crew members of local newspapers in Rivers and Bayelsa States. The researchers used the census technique to study the entire population. Data for the study were generated using documents and the questionnaire. The data obtained from questionnaire were analysed using simple percentages. The study found out that 82 local newspapers existed in the two states within the period of study. The local newspapers with the longest lifespan published for upward of eleven to fifteen years, while the ones with the shortest lifespan existed less than five years. The study also found out that the lifespan of local newspapers in Bayelsa State was longer than the ones in Rivers. The study recommended that publishers and prospective local newspaper proprietors should strive towards quality production in content and design to improve circulation. They should put in place requisite requirements for the publication of newspapers to remain afloat.
\end{abstract}

Keywords: Lifespan, local newspapers, survival, extinction

DOI: $10.7176 / \mathrm{NMMC} / 84-05$

Publication date:October $31^{\text {st }} 2019$

\section{Introduction}

Newspaper is believed to be one of the oldest conventional mass medium that engages the citizens in the exchange of ideas for the advancement of the society. It is said to be a serial publication which contains news on current events of special or general interest. Omego and Ochonogor (2012) define newspaper as "any paper concerning public news, intelligence or occurrences or any remarks, observations or comments printed therein for sale and published periodically or in parts or numbers" (p.110). A German scholar, Otto Groth, in 1928 developed a set of five criteria to determine what a true newspaper is. Bittner (1989) explains that the first criterion of the set of five standards to determine a true newspaper is that the newspaper must be published periodically at intervals not less than once a week. The second criterion is that mechanical reproduction must be used to produce the copies. The third criterion requires access to the publication for those who can afford to pay the price. The fourth standard stipulates that the contents must vary and should include issues of public interest and the fifth is that the publication must be timely with some continuity of organisation.

Nigerian newspapers are said to be one of the most vibrant in Africa due to the prominent roles they played in the decolonisation process, nationalistic movement and enthronement of democracy (Coleman, 1971; Omu, 1974; Olukotun, 2003; Adesoji and Hahn, 2011). Newspapers take different forms and classifications. Ukonu (2006) notes that there are newspapers in the contemporary times that are purely devoted to specialised topics such as literary affairs, sports, financial matters, politics and religion.

A newspaper has the advantage of conveying detailed and timely information that register longer in the minds of the readers. Newspaper also possesses the added advantage of accessibility for further reference. Thus, several scholars have recognised newspaper as more significant than other forms of mass media such as radio and television (Reddick, 1976; Ferguson and Weigold, 1986; Allen and Izcaray, 1988; Ferguson and Patten, 1993; McQuail, 1994; Schaffner \& Sellers 2003; Baran, 2004; Waal, SchÖnbach and Lauf, 2005 and Lee, 2009). Uwakwe (2005), on the other hand, rates the broadcast media highly for providing instant news gratifications to the audience through the advantage of immediacy. Citing Hahn (1998), Uwakwe (2005) captures the comparison among the broadcast and print media thus:

TV supplies almost no history, newspapers some, magazines even more, books most of all. That is, the slower the medium in question the more it supplies the historical context. But note that the public favours the slower media much less than the faster; that is, more people watch television than read newspapers; more read newspapers than magazines; more read magazines than books. The result is that although many people know what happened today, few understand why it happened and how it relates to other events today and yesterday, or that there may be systemic causes rather than unreasoned and unreasonable random causes (p.163) 
The important issue for the study however, is not about the most vibrant medium or media of communication, as scholars have established that one form of mass media tends to complement the other for the overall responsibility of disseminating information to the audience or readers. The foregoing is supported by Roger Fidler's 'mediamorphosis' which holds that the new media do not arise spontaneously or independently but that they emerge gradually from existing media while the older media tend to adapt and evolve continuously rather than to die.

The focus of this study is the local newspaper. Bland, Theaker and Wragg (2004) describe local newspapers as the form of newspapers that are published weekly, twice weekly and fortnightly with small editorial teams. They note that local newspapers maintain local links with their readers. "Local newspapers can be divided into the traditional 'paid-for' publications and the more recent 'freesheets', supported entirely by advertising. These are augmented in some areas by community newspapers, sometimes run by volunteers, but sometimes inspired by the local authority" (p.53). Bland et al (2004) also note that "local newspapers place a great reliance on a network of unpaid contributors, who provide news of local events and organisations... Most journalists feel that the great national daily newspapers are the most important. In one sense this is true... On the other hand, many members of the public pay more attention to their local newspapers..." (p.54). Jimada (2006) describes local press as people's forum that provides the avenue for the people to read more about themselves and development activities around them.

The local newspapers are critical to development at the local level. The submission that local newspapers are critical to development at the local setting is given impetus by the position of Oyedele, Osezua, Abdulkareem and Ishola (2017) that greater number of Nigerian population resides in the rural areas which means that the participation of inhabitants of local areas in democratic process will bridge the gap in government-citizen relationship and foster development. Underwood (1998) underscores this fact in his submission that "in recent years, many daily newspapers have put a stronger emphasis upon local issues coverage that they believe will appeal to the parochial interest of readers" (p.175). In further assertion to this, Nielson (2014) captures the critical role of the local newspapers thus:

local media have represented their area and helped people imagine themselves as part of a community, connected in part through their shared local news medium, bound together by more than geographic proximity or politically defined administrative boundaries...It provides information about local public affairs, it holds local elites at least somewhat accountable, it provides a forum for discussion, and it ties communities together (p.1).

The choice of the two states was informed by the fact that apart from probably Lagos State, Rivers and Bayelsa States seem to record considerable number of local newspapers in Nigeria within the period covered by the study. This inference was deduced from the studies of Adamu (1999) and Odorume (2012) including the data obtained at https://en.wikipedia.org/wiki/Category:Newspapers_by_cityji. The period from 1990s witnessed the establishment of more private newspapers in Rivers and Bayelsa States, just as there were cases of extinction and inconsistencies in the production of local newspapers in the states.

\subsection{Statement of the problem}

Local newspapers are published for various reasons ranging from politics, social agitation, crusading for causes, business, amongst others. Between 1996 and 2016, many of such newspapers were observed to be in existence in Rivers and Bayelsa States. There is the need to historically document the existence of these local newspapers for posterity. There is also the need to examine the local newspapers within the period to find out the duration of their existence, with a view to ascertain those that are dead and those that have lived beyond the period under study. Such investigation will provide research pedestal for future studies on what is responsible for their differences in lifespan.

Also, there seems to be little or no basic researches on the existence and lifespan of local newspapers in any part of Nigeria, hence, the need to begin with Rivers and Bayelsa States. Therefore, the thrust of the study is: what local newspapers had existed and their lifespan in Rivers and Bayelsa States between 1996 and 2016 ?

\subsection{Aim and objectives of the study}

This study aims at documenting the local newspapers in Rivers and Bayelsa States between 1996 and 2016. The objectives of the study are to:

1 Find out the local newspapers that were published in Rivers and Bayelsa States between 1996 and 2016.

2 Ascertain the lifespan of the local newspapers that were published in Rivers and Bayelsa States between 1996 and 2016.

3 Ascertain between Rivers and Bayelsa States which had longer lifespan of local newspapers between 1996 and 2016. 


\subsection{Research questions}

The following research questions guided this study. They are:

1 Which local newspapers were published in Rivers and Bayelsa States between 1996 and 2016 ?

2 What was the lifespan of the local newspapers that were published in Rivers and Bayelsa States between 1996 and 2016?

3 Between Rivers and Bayelsa which state recorded the local newspapers with longer lifespan of local newspapers between 1996 and 2016?

\section{Theoretical Framework}

\subsubsection{Circulation spiral theory}

The circulation spiral theory of the media which was first articulated by Lars Furhoff in 1967, describes the interaction that exists between the newspapers and the advertising markets and how the interaction affects the circulation of newspapers with smaller readership by contributing to their extinction when they could not withstand the competition from other newspapers. Furhoff (1973) asserts that smaller newspapers lose readers since they are less attractive to advertisers and are poorly circulated to the public. Thus, the first interpretation of advertising-driven spiral entails that the survival of newspapers to a great extent, is tied to the size of the readers. This is because the newspapers with larger circulation will attract more economic fortunes but the ones with smaller circulation will lose advertising patronage and may face extinction, while the second interpretation is of the submission that more readers will attract more advertising revenue and enable the newspapers to attain higher quality.

According to Gustafsson (1978), Lars Furhoff developed the theory in his study of the interaction between the newspapers and advertising markets. The theory posits that the larger of two competing newspapers is favoured by a process of mutual reinforcement between circulation and advertising, as a larger circulation attracts advertisements, which increase the circulation, and in turn attracts more advertising and again more readers. Contrarily, the smaller of two competing newspapers is caught in a vicious circle; its circulation has less appeal for advertisers, and it loses readers if the newspaper does not contain attractive advertising. A decreasing circulation again aggravates the problems of selling advertising space, so that finally the smaller newspaper will have to close down.

Given the submission of the circulation spiral theory, local newspapers in Rivers and Bayelsa States, will ordinarily not survive for too long if they are to depend on advertising for funding. The fear that the local newspapers may not survive for too long is hinged on the premise that they cover small readership which may not suitably appeal to advertisers. Several studies have established that advertisers are major stakeholders in the funding of mass media and are favourably disposed to newspapers with large readership and circulation.

The funding of newspapers falls under the economics of the media. Media economics is concerned with the revenue generation and financing of the mass media. Funding is required for the production of newspapers, payment of staff and office upkeep. All the relevant stakeholders comprising the newspaper owners, readers and advertisers expect one form of benefit or the other from the media. The major source of revenue generation for most newspapers, especially non-government sponsored newspapers is advertising. Patterson and Wilkins (1998) state that "advertising provides financial support to the media, keeping the media free from government ownership or direct subsidies and the controls that go with them. The price of this "free" information-news and entertainment - is embedded in the price of advertised goods we purchase" (pp.65-66). Baran (2004) notes that "...The newspaper was also the first mass medium to rely on advertising for financial support, changing the relationship between audience and media from that time on" (p.101).

Advertising is very critical to the effective marketing of newspapers. It entails a tripartite or triangular relationship consisting of the advertiser, consumer and the media. Okon (2006) explains that "the advertiser pays money to the media. The media in turn render specialised services to the advertiser in terms of media exposure. This media exposure on the other hand, affords the consumers the opportunity of knowing and liking the product. By acting on it, the consumer makes a positive buying decision and by so doing enriches the advertiser" (p.37). Mass media need funds to offset production cost, pay workers and generate profits to the owner. The financial processes involved in the production of newspapers also contribute to national economic development. The Marketing Department of newspapers mostly relies on sale of space through advertising than sale of the newspaper for the financial sustenance of the newspaper. There is also the revenue generated from circulation. This is because, newspapers are not only published; they must be circulated to reach the readers. Ferguson and Patten (1993) aver that "just getting your publication printed is not enough; you have to have readers. Circulation is another function usually assigned to the business staff" (p.306). In a study by the World Press Trends made public in 2017, the World Association of Newspapers and News Publishers (WAN-IFRA) revealed that in 2016, 56 per cent of newspapers' overall revenue came from circulation sales. Chief Executive Officer of WAN-IFRA, Vincent Peyrégne, while presenting the key findings from the global study at the $69^{\text {th }}$ World News Media Congress and $24^{\text {th }}$ World Editors Forum in Durban, South Africa, stated that the shift from advertising to reader- 
based revenue was reshaping the fundamentals of the newspaper industry.

Schweizer, Puppis, Kunzler and Studer (2014) also list direct and indirect form of support as the types of public funding of the media. Indirect subsidies are support measures that assist media houses to create a favourable economic situation. It could be in the form of tax relief and advertising patronage by the state. Živkovic (2016) states that "Governments have continued handing money to media owners in the usual ways, mostly through tax deductions, through state advertising, and by other forms of indirect support. In most of the EU and elsewhere in the region, newspapers enjoy a reduced, or even a zero, value-added tax rate" (pp.4-5). The introduction of newspaper subsidies in 1969 for four groups of newspapers was intended to prevent the extinction of newspapers. The groups were the local daily newspapers, some specialised national dailies, national non-daily newspapers and the smallest local newspapers. Direct subsidies take the form of funding assistance or payments made to media organisation. Živkovic (2016) recalls that the Swedish government provided financial assistance to the media to the tone of 53 million euro in 2013. Norwegian government directly subsidised the media with the sum of 44 million euro in 2013, while in Austria, the media received subsidies worth 11 million euro and the French government spent 615 million euro on newspapers and other news media in 2012.

Acknowledging the importance of local newspapers in the development of their local areas, the Norwegian newspapers recorded as the highest consumption newspapers between 1972 and 1997 in the world were assisted with subsidies from government and other agencies. Same succour came the way of newspapers in Sweden through provision of production support for its weeklies by the Swedish government (HØst 1999). Also, a United States-based Foundation, the Democracy Fund in February 2018 announced an endowment of \$2 million to fund local news in New Jersey and North Carolina (Gorman and Sterns, 2018). The subsidies to the media contributed to the sustainability of the media.

On whether the media houses that receive subsidies from government would not eventually become the megaphone of the government, Živkovic (2016) argues that "Media systems with no direct subsidies, such as those in Hungary, Bulgaria, and Croatia, frequently attract criticism for fostering sinister entanglements between media and governments. Meanwhile, countries with a tradition of active media policies, manifested in the direct subsidizing of media, regularly rank highest in media freedom" (p.6). Supporting the argument that providing subsidy may not really influence the media, Sparks (1991) as cited in Gillwald (1993) avers that "just as subsidies do not necessarily mean government intervention in the content of the press, neither does its absence guarantee non-interference" (p.75).

However, the ethical issue arising from whether it is right for the state to fund journalism that serves public interest gives way to the development of several models for sustainable funding of independent media. The models, according to Živkovic (2016) include: Grant from lottery revenue, the Finnish model, citizenship news vouchers model, crowd-funding model and philanthropy model. The grant from lottery revenue started in Croatia in 2013 successfully assisted some non-profit news organisation to run effectively in their onerous task of disseminating information to the public. The Finnish model supports the mass-circulation of privately-owned print media and enhances journalistic professionalism through a strong tradition of public service journalism and economic interventions by the state. The citizenship news vouchers model by McChesney and Nichols (2010) proposes that citizens support the non-profit news organisations of their choice with $\$ 200$ by enlisting the news organisation on their tax returns or filling in a simple form. Liu (2016) defines crowd-funding "as a way to finance reporting by micropayments from ordinary people. It is part of a general phenomenon called crowdsourcing, a term coined by Jeff Howe in an article from Wired magazine in 2006" (p.4). In crowd-funding, according to Liu (2016), the crowd makes financial contributions. The idea of crowd-funding journalism is that through the donations from the crowd, massive projects that will be difficult for an individual media owner to implement could be funded through the intervention. Živkovic (2016) citing McChesney and Nichols (2010) states that "this funding mechanism is the centrepiece of our policy recommendations, and we mean it to apply to public, community and all other non-profit media structures, including the new generation of post-corporate newspapers (p.13).

On philanthropy model, Živkovic (2016) points out that in the United States, for instance, over 2,700 foundations donated more than 2.2 billion dollars to over 7,000 non-profit media organisations between 2009 and 2012. Živkovic (2016) adds that many philanthropic foundations, such as the Open Society Foundations, have embarked on supporting independent media, be they non-profit or commercial media, necessitating the Open Society Foundations to make budgetary provision of 21.3 million dollars in its 2016 budget

\section{Methodology}

The use of library sources and survey were the research designs for the study. The library sources involved the use of documents from ministries of information in the two states, the publishers' associations, periodicals and other relevant sources. The population of the study was drawn from 214 production crew members of local newspapers in Rivers and Bayelsa States. The production crew comprised publishers, editors and reporters. Due to death and migration which made it difficult to locate some of the persons listed in the categories above, former 
employees of the newspapers such as computer operators and circulation managers were used to fill the absence of those members of the production crew. Census was used to study the entire population. Accordingly, 214 print media workers were all studied.

\section{Results and Discussion}

4.1 Presentation of data

Research Objective One: Find out the local newspapers that were published in Rivers and Bayelsa States between 1996 and 2016

Local Newspapers in Rivers State

The Tide

The Port Harcourt Telegraph

The Argus

Hard Truth

Africa Update

Treasure Base

News Scroll

Neighbourhood

South South Voice

Evening Waves

The Peoples Herald

Galaxy

Continental Eagle

The Trumpet

Reformer

Surveillance

Envoy

Newspoint

The Mirror

The Signal

Public Express

South South Crow

National Point

National News Leader

Rivers Express

Balanced News

Popular View Newspaper

Independent Monitor

The Beacon

National Network

Today's Top News

Notable Outcome

The Gist

Port Harcourt Spectator

Weekly Watch

Newswriter

PH Sunrise

Eagles News

The Beam

Times Express

Plain Truth

The Moonlight

Eastern Delta Times

Verite

The Provider

News Desk (now Rivers Today)

Mandate Quest

PM News

Niger Delta Today

South South Express

Mega News

The Dolphin Newspaper

The Wish

The New Nationalist

\section{Local Newspapers in Bayelsa State}

New Waves

Izon Times

National Concept

State Graphics

Dispatch

Dialogue

The Light

Hard News

Atlantic Express

Global Overseer

People's Reflection

Egberi Newspaper

Coastal News Network

The Bullet

From the local newspapers listed above, 82 newspapers consisting of 54 newspapers in Rivers and 28 newspapers in Bayelsa were published in the two states within the period covered by the study. The lists of these local newspapers were obtained from the ministries of information in the two states, journalism associations and other library sources. Some other local newspapers that failed to register with the relevant bodies may have been omitted in the list.
The Canon
AM Times

Niger Delta Details

The Goose

Bull River

Izon-Link

Niger Delta Herald

Banner News

Weekly Source

New Agenda

Watchman
Creek News

Crystal Express

Opinion Newspaper 
Research Objective Two: Ascertain the lifespan of the local newspapers that were published in Rivers and Bayelsa States between 1996 and 2016

Table 4.1: Lifespan of the Local Newspapers (LN) in Rivers and Bayelsa States

\begin{tabular}{lcccc}
\hline Lifespan & L N in Rivers & L N in Bayelsa & Total & $\%$ \\
$0-5$ yrs & 7 & 2 & 9 & 10.98 \\
$6-10$ yrs & 16 & 10 & 26 & 31.71 \\
$11-15 y r s$ & 24 & 12 & 36 & 43.90 \\
16-20yrs & 7 & 4 & 11 & 13.41 \\
\hline TOTAL & $\mathbf{5 4}$ & $\mathbf{2 8}$ & $\mathbf{8 2}$ & $\mathbf{1 0 0}$ \\
\hline
\end{tabular}

The data in Table 4.1 above show that the local newspapers with the longest lifespan published between 11 and 15 years, while shortest lifespan is between 0 and 5 years.

Table 4.2: Status of Newspapers published between 1996 and 2016

\begin{tabular}{lcccc}
\hline Status & Rivers & Bayelsa & Total & $\%$ \\
Existing & 26 & 24 & 50 & 61 \\
Dead & 28 & 4 & 32 & 39 \\
\hline TOTAL & $\mathbf{5 4}$ & $\mathbf{2 8}$ & $\mathbf{8 2}$ & $\mathbf{1 0 0}$ \\
\hline
\end{tabular}

Table 4.2 shows that $61 \%$ of the local newspapers in Rivers and Bayelsa States were functional between 1996 and 2016 , while $39.02 \%$ of the local newspapers in the two states went extinct.

Table 4.3: Surviving Newspapers between 1996 and 2016

\begin{tabular}{lcccc}
\hline Status & Rivers & Bayelsa & Total & \% \\
Regular & 6 & 7 & 13 & 26 \\
Fairly regular & 5 & 5 & 10 & 20 \\
Irregular & 15 & 12 & 27 & 54 \\
\hline TOTAL & $\mathbf{2 6}$ & $\mathbf{2 4}$ & $\mathbf{5 0}$ & $\mathbf{1 0 0}$ \\
\hline
\end{tabular}

Table 4.3 shows that $20 \%$ of the local newspapers that published in Rivers and Bayelsa States between 1996 and 2016 had fairly regular publications. The Table also shows that 54\% of the local newspapers had inconsistent publications.

Table 4.4: Extinct Newspapers between 1996 and 2016

\begin{tabular}{lcccc} 
& \multicolumn{1}{c}{ Table 4.4: Extinct Newspapers between 1996 and 2016 } \\
\hline Status & Rivers & Bayelsa & Total & $\%$ \\
0-5years & 6 & 0 & 6 & 18.75 \\
6-10years & 13 & 0 & 13 & 40.63 \\
11-15years & 9 & 4 & 13 & 40.63 \\
16-20years & 0 & 0 & 0 & 0 \\
\hline TOTAL & $\mathbf{2 8}$ & $\mathbf{4}$ & $\mathbf{3 2}$ & $\mathbf{1 0 0}$ \\
\hline
\end{tabular}

Table 4.4 shows that $18.75 \%$ of the local newspapers in Rivers and Bayelsa States which had gone extinct within the period of the study lasted from one to five years. The Table also shows that $40.63 \%$ of the local newspapers which had gone extinct lasted equally between 6-10 years and 11-15 years, respectively.

Research Objective Three: Between Rivers and Bayelsa which state recorded the local newspapers with longer lifespan?

The local newspapers in Bayelsa State recorded longer lifespan than the local newspapers in Rivers State within the period covered by the study. This is premised on the outcome of the investigation of 82 local newspapers for the two states out of which Bayelsa had just 28 newspapers, while Rivers had 54 local newspapers. For the 50 surviving newspapers recorded in the study, Bayelsa which had the lower number of overall newspapers however, had 7 active and regular newspapers representing 14\% of local newspapers that published regularly, while Rivers State with the higher number of newspapers had $6(12 \%)$ active and regular newspapers. Also, more local newspapers numbering 28 (87.5\%) went extinct in Rivers State, while only 4 (12.5\%) went extinct in Bayelsa State as shown in Table 4.2. The data also show that for the 50 surviving local newspapers, Rivers had $26(52 \%)$, while Bayelsa had $24(48 \%)$ as shown in Table 4.3.

\subsection{Discussion of findings}

For research question one, using library sources, a total of 82 local newspapers published in Rivers and Bayelsa States between 1996 and 2016. From the figure, Rivers State recorded 54 local newspapers, while Bayelsa State had 28 local newspapers. This figure attests to the fact that the publication of local newspapers flourished in the two states within the period covered by the study. The finding lends credence to Underwood's (1998) submission that in recent years, many newspapers have put a stronger emphasis upon local issues coverage that they believe will appeal to the parochial interest of readers. 
For research question two, the data in Tables 1-4 show that the local newspapers with the longest lifespan were those published for over ten years but not more than fifteen years. They were 36 newspapers representing $43.90 \%$. The record also shows that the local newspapers that published between six and ten years had the second longest lifespan with a total of 26 which is $31.71 \%$, those that lasted between sixteen and twenty years were 11 representing $13.41 \%$, while the ones that lasted between five years and below were 9 representing $10.98 \%$.

A further breakdown of the figure shows that for the category with the longest lifespan (11-15 years) which were 36 newspapers, Rivers had 24 local newspapers representing 66.67\% and Bayelsa had 12 local newspapers representing 33.33\%. For the 26 local newspapers that published between 6 and 10 years, Rivers had 16 representing 61.54\% and Bayelsa 10 newspapers constituting 38.46\%. For the 11 local newspapers published between 16 and 20 years, Rivers had $7(63.64 \%)$ and Bayelsa 4 (36.36\%), while the 9 newspapers with the shortest lifespan (0-5 years), Rivers had 7 (77.78\%) and Bayelsa recorded $2(22.22 \%)$.

The data further show that a total of 50 local newspapers representing $61 \%$ survived, while 32 representing $39 \%$ went extinct within the 20 years period of study. Among the newspapers that survived, 27 representing 54\% had irregular publications, 13 representing 26\% published regularly, while 10 representing $20 \%$ were fairly regular. The data also show that for the 50 surviving local newspapers, Rivers had $26(52 \%)$, while Bayelsa had $24(48 \%)$. Of this figure, 15 of them representing $30 \%$ were irregular in their publications in Rivers, while Bayelsa recorded $12(24 \%)$ irregular newspapers. Both Rivers and Bayelsa States shared equal $5(10 \%)$ newspapers as fairly regular, while Rivers had 6 local newspapers representing 12\% as regular and Bayelsa had 7 (14\%) that published regularly (Table 4.3).

Table 4.4 shows that 32 local newspapers went extinct. Of the figure, 6 newspapers representing $18.75 \%$ published not more than five years, 13 newspapers representing $40.63 \%$ existed not more than ten years and another 13 newspapers published not more than fifteen years. A further breakdown of the table also shows that a total of 28 local newspapers representing $87.5 \%$ were based in Rivers State, while 4 local newspapers constituting 12.5\% were based in Bayelsa State.

For research question three, it was found out that local newspapers in Bayelsa State had longer lifespan than their counterparts in Rivers State. This is premised on the basis that at the level of the 50 surviving newspapers, Bayelsa had 7 active newspapers representing 14\% of local newspapers that published regularly, whereas Rivers State had $6(12 \%)$ active and regular newspapers. It is also premised on the fact that more local newspapers numbering $28(87.5 \%)$ went extinct in Rivers State, while only $4(12.5 \%)$ went extinct in Bayelsa State as shown in Table 4.2 .

The scenario was similar to the case in British Columbia in which only 13 newspapers survived out of 36 newspapers within a period of 10, according to McElroy (2016). It also lends credence to the study undertaken by the Center for Research Libraries to assess African newspapers online in 2012 which concluded that the lifespan of some African print newspapers was in grave danger.

\section{Summary, Conclusion and Recommendations 5.1 Findings}

From the data presented and analysed, the study found out that:

1. A total of 82 local newspapers with Rivers State having 54, and Bayelsa State 28 newspapers published between 1996 and 2016.

2. The local newspapers with the longest lifespan published for upward of eleven to fifteen years, while the ones with the shortest lifespan existed less than five years.

3. The local newspapers in Bayelsa State proved to have been better managed than the ones in Rivers State between 1996 and 2016. This finding was based on the premise that only few local newspapers in Bayelsa State went extinct within the period covered by the study.

\subsection{Conclusion}

Having documented and examined the lifespan of local newspapers that existed in Rivers and Bayelsa States within a period of twenty years, the study concludes that the existence of local newspapers in the two states was abysmally poor as the number of newspapers that went extinct on the average was alarming. The study validates the circulation spiral theory that local newspapers risk sustainability due to poor circulation and low readership.

\subsection{Recommendations}

Consequent upon the findings of the study, the following recommendations were considered useful:

1 To ensure professionalism in print media practice at the local level, more stakeholders are encouraged to show interest in the activities and operations of local newspapers in Rivers and Bayelsa States.

2 In order to forestall short lifespan for local newspapers in Rivers and Bayelsa States, regulatory bodies should ensure that the requisite requirements are met before the establishment of local newspapers. This 
recommendation is premised on the finding that the majority of the newspapers did not do well on the average within the period covered by the study.

3 Publishers of local newspapers in Rivers State should regularly review their performances to ensure that the newspapers meet the aspirations of the readers and other critical stakeholders.

\section{References}

Ball-Rokeach, S. J., \& DeFleur, M. L. (1976). A dependency model of mass media effects. Communication Research, 3, 3-21.

Bland, M., Theaker, A., \& Wragg, D. (2004). Effective media relations ( $2^{\text {nd }}$ edition). London: Kogan Page Limited.

Cag'e, J. (2014). The economics of the African media. Retrieved from https://spire.sciencespo.fr/hdl:/2441/5ut30aqjfo8h69p4jd9j3iu2em/resources/economics-african-mediacage-2014-1.pdf on 21-9-2018.

Coleman, J. S. (1971). Nigeria: Background to nationalism. Berkeley: University of California Press.

Emery, E. (1972). The press in America (5 ${ }^{\text {th }}$ ed). Englewood Cliffs, New Jersey: Prentice Hall.

Esipisu, I., \& Kariithi, N. (2007). New media development in Africa. In Global Media Journal, 1(1), 1-45.

Gorman, T. \& Stearns, J. (2018, February, 7). Local people will create the future of local news. Retrieved from https://www.democracyfund.org/blog/entry/local-people-will-create-the-future-of-local-news on 03-12-2018.

HØst, S. (1999). Newspaper growth in the television era: The Norwegian experience. Retrieved from http://cite seerx.ist.psu.edu/viewdoc/download?doi=10.1.1.692.350\&rep=rep1\&type=pdf on 14-02-2018.

Ige, J. B. (2013). Imperative of total newspapering for survival in Nigerian industry. Arabian Journal of Business and Management Review (OMAN Chapter), 2 (8), 84-94.

Jimoh, I. (2016). Role of elections in the survival of Nigerian newspapers: The experience of Daily Trust and Punch newspapers. Journal of Communication and Media Research, 8 (6), 177-200.

Meyer, P. (2008). The elite newspaper of the future. American Journalism Review. Retrieved from http://www. ajr.org/article printable.asp?id=4605 on 12-01-2017.

Meyer, P. (2009). The vanishing newspaper: Saving journalism in the information age (2 ${ }^{\text {nd }}$ ed).USA: University of Missouri Press.

Mosco, V. (1996). The political economy of communication: Rethinking and renewal. London: Sage.

Nielson, R. K. (2015) (ed). Local journalism: The decline of newspapers and the rise of digital media. Retrieved from www.ibtauris.com/reuters on 7-09-2017.

Obijiofor, L., \& Green, K. (2001). New technologies and future of newspapers. Asia Pacific Media Educator, 11, 88-99.

Obijiofor, L. (2003). New technologies and journalism practice in Nigeria and Ghana. Asia Pacific Media Educator, 14, 36-56.

Odorume, A. (2012). Historiography of the print media: A global-cum-Nigerian perspective. Mgbakoigba: Journal of African Studies, 1, 1-9

Ogan, C. (2012). Alfred Diete-Spiff: A legacy of development in the Niger Delta. Port Harcourt: Onyoma Research Publications.

Omu, F. I. A. (1974). Journalism and the rise of Nigerian nationalism: John Payne Jackson, 1848-1915. Journal of the Historical Society of Nigeria, vii(3), 521-539.

Omu, F. (1978). Press and politics in Nigeria 1880-1937. Ibadan: Longman Group Limited.

Oyedele, S. O., Osezua, E. M., Abdulkareem, A. K., \& Ishola, A. A. (2017). Local government administration and national development in Nigeria: Challenges and prospects. Ilorin Journal of Human Resource Management 1(1), 142-154.

Preston, P. (2017, September 10). A new silence at the grassroots as local newspapers fade away. Retrieved from https://www.theguardian.com/media/2017/sep/10/new-silence-grassroots-local-news-fades on $31 / 12 / 17$.

Thurman, N. \& Myllylahti, M. (2009). Taking the paper out of news: A case study of Taloussanomat, Europe's first online-only newspaper. In Journalism Studies, 10(5), 691-708.

Udoakah, N. J. (2017). The political economy of Nigerian journalism. Being the $54^{\text {th }}$ Inaugural Lecture of University of Uyo. Uyo: Dorand Publishers.

Underwood, D. (1998). Market research and the audience for political news. In D. Graber; D. McQuail. \& P. Norris (Eds.). The politics of news: The news of politics. USA: CQ Press.

Wasko, J. (2014). The study of the political economy of the media in the twenty-first century. International Jou/rnal of Media and Cultural Politics, 10 (3), pp. 259-271. 